\title{
ニューラルネットワークによる 都市中小河川感潮域の水位推定 \\ RIVER LEVEL ESTIMATION USING ARTIFICIAL NEURAL NETWORK FOR URBAN SMALL RIVER IN TIDAL REACH
}

\author{
高崎忠勝 1 ・河村明 2 ・天口英雄 ${ }^{3}$ \\ Tadakatsu TAKASAKI, Akira KAWAMURA and Hideo AMAGUCHI \\ 1正会員 博(工) 東京都土木技術支援・人材育成センター 技術支援課（†136-0075 東京都江東区新砂1-9-15）
2正会員 工博 首都大学東京大学院教授＼cjkstart都市環境科学研究科（†192-0397 東京都八王子市南大沢1-1）
3正会員 博(工) 首都大学東京大学院助教＼cjkstart都市環境科学研究科（†192-0397 東京都八王子市南大沢1-1）
}

Prediction of water level in small rivers is great interest for flood control in an urban area located in the river mouth. The tidal river water level is affected by not only flood discharge but also tide, atmospheric pressure, wind direction and speed. We propose a method of estimating river water level considering these factors using an artificial neural network model for the Kanda River located in the center of Tokyo. The effects by those factors are quantitatively investigated. As for the effects by the atmospheric pressure, river water level rises about $7 \mathrm{~cm}$ per $5 \mathrm{hPa}$ increase of the pressure regardless of river discharge under the conditions of $1 \mathrm{~m} / \mathrm{s}$ wind speed and north wind direction. The accurate rating curve for the tidal river is finally obtained.

Key Words : artificial neural network, tidal river, urban area, river level, atmospheric pressure, wind direction, wind speed

\section{1. はじめに}

都市中小河川では浸水被害が頻繁に発生しているもの の河川拡幅が困難なことから，感潮区間である下流域に おいても地下調節池の整備が進められている1). 施設の 設計に際しては水理模型実験や水理解析が行われるが, 適切な検討を行うためには水位と流量の関係を正確に把 握することが望まれる.

感潮域では流量が一定值であっても潮汐，気圧，風向， 風速の条件によって偏差が生じ，河川水位は様々な值を とる.このため河川水位の推定に水位流量曲線を用いる ことができず，水位予測を行う場合においても満倉ら はパターン認識手法であるNearest-Neighbor法を用いる方 法, 渡辺ら ${ }^{3)}$ は土知能技術である遺伝的プログラミン グを用いる手法を提案しており，水位と流量の関係を用 いない方法がとられている.

近年では流速を連続して計測することで感潮域におい ても流量モニタリングが可能となっており，横尾ら苂は 感潮域において流量モニタリングと気象観測を行い，潮 汐，気圧，風の効果を除去した流量のみに依存する水位
を算定している. 感潮域においても潮汐, 気圧, 風の条 件を固定することにより水位と流量の関係を一意に表す ことが可能だと考えられる，しかし，都市中小河川の出 水は短時間に行われるため, 様々な潮汐や気象の条件下 において水位と流量の関係把握に十分なデータを取得す ることは難しい.

生物神経系の機能を模擬したモデルであるニューラル ネットワークモデル（ANN）は，実績データの学習結 果をもとに予測計算を行う手法であり，安部ら5は流出 解析に対してANNを適用しタンクモデルとの比較を行 いその有用性を検討している。 また，稲吉らのは出水の 早い二級河川の洪水予測を対象にANNを使用し，雨 量・水位の観測值から直接に基準地点の水位を予測して いる. ANNは非線形の連続関数を近似できる点が特長 であり，感潮域における水位・流量の関係把握に対して も活用できると考えられる.

本研究は, 都心部を流れる神田川の感潮域を対象に, 規定した潮汐，気圧，風条件における水位と流量の関係 を明らかにすることを目的としている。まず，現地にお ける流量モニタリング結果をもとに水位, 流量, 潮位の 関係を検討する. 次に, 河川モニタリングデータと潮汐, 
気圧, 風向風速データを用いて, 河川水位の偏差と各項 目の関係を検討寸る.さらに，検討に用いたデータを学 習させたANNによって, 潮汐, 気圧, 風向風速, 流量 を指定したときの水位を計算し，これらの要因が水位に 及ぼす影響を示す。

\section{2. 対象地点の状況および観測結果}

本研究が対象とする神田川美倉橋地点の位置および断 面を図-1に示す．神田川は三鷹市の井の頭池を源とし都 心部を流下し，千代田区で日本橋川と分派し，台東区で 隅田川に注ぐ延長 $25.48 \mathrm{~km}$ の荒川水系の河川である．美 倉橋地点は隅田川合流点から $0.7 \mathrm{~km}$ 上流にあり，感潮域 に位置している．この地点では表-1に示すように計152 回の流量観測を実施しており，このうち118回の観測は ADCPを用いて行っている. また，護岸に取り付けた流 速計（電磁式・RF低水用，愛知時計電機（株）製）と 水位計によって護岸付近の流速と河川水位を連続的に計 測しており, 流量時系列を把握している. 平水時の流量 は後述する水位変化速度から推定し, 出水時の流量は表 -1に示した観測で得られた流量と流速計の流速データか ら作成した関係式より推定した。 なお，出水時は流域内 で降雨があり直接流出量が発生している状況であり，平 水時は直接流出量が生じていない状況を想定している. 本研究ではこうした河川モニタリングデータについて 2007年10月から2009年10月の期間のデータを用いた。 た だし，2008年10月から2009年3月の期間は計測機器の故 障により欠測している.

図-2に, 平水時の流量と水位・潮位の時系列変化を示 す。図中の潮位は東京都中央区晴海に位置する気象庁東 京の実測潮位を表わしている。モニタリング流量は護岸 に取り付けた流速計・水位計の計測データから推定した 流量であり，観測流量は流量観測調查によって得られた 流量を示している. 平水時の河川水位は潮位とほとんど 同じ動きをしており，満潮時および干潮時の河川流量は 概衫 $0 \mathrm{~m}^{3} / \mathrm{s}$ こなっている. この原因として潮汐の影響を 受けない曙橋地点の平水時の流量が $4 \mathrm{~m}^{3} / \mathrm{s}$ 程度と小さく, また，日本橋川への分派もあり，上流から感潮区間に流 入する河川流量が小さいことが考えられる．都心部を流 れる二級河川についても感潮区間より上流の流量が極め て少ないため, 美倉橋同様に潮汐が水位や流量を決定し ていると考えられる.

図-3に，出水時の流量と水位・潮位の時系列変化を示 す. 図中の降水量は気象庁東京の降水量を表わしている. 1 時間に $3 \mathrm{~mm}$ 以下の降水量が観測されている7日につい てみると河川水位は実測潮位とほとんど同様の変化をし ているが，1時間に40mmを超える極めて強い雨が観測さ れた8日4時をみると，河川水位は実測潮位より $0.97 \mathrm{~m}$ 高 くなっている.

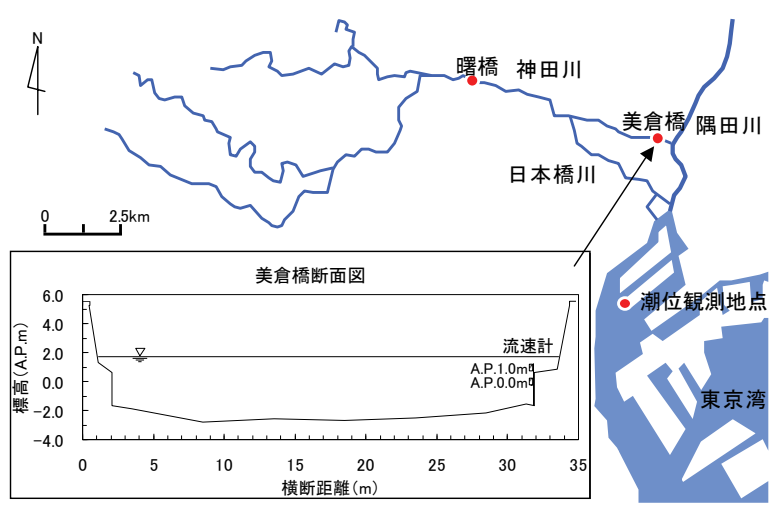

図-1 対象地点

表-1 流量観測

\begin{tabular}{|c|c|c|c|}
\hline 観測日時 & 観測回数 & 降雨 & 使用機器 \\
\hline $2008 / 1 / 226: 00 \sim 1 / 2213: 00$ & 8 & 無し & 流速計(橋上から計測) \\
\hline $2008 / 1 / 296: 00 \sim 1 / 2917: 00$ & 12 & 無L & 流速計(橋上から計測) \\
\hline $2008 / 2 / 26 \quad 19: 00 \sim 2 / 27 \quad 6: 00$ & 12 & 有り & 流速計(橋上から計測) \\
\hline $2008 / 8 / 1 \quad 10: 00 \sim 8 / 2 \quad 9: 00$ & 24 & 無L & ADCP(橋上から曳航) \\
\hline $2008 / 9 / 1912: 00 \sim 9 / 2111: 00$ & 48 & 有り & ADCP(橋上から电航) \\
\hline $2009 / 8 / 1018: 00 \sim 8 / 1120: 00$ & 24 & 有り & ADCP(橋上から曳航) \\
\hline $2009 / 10 / 721: 00 \sim 10 / 821: 00$ & 24 & 有り & ADCP(橋上から曳航)，浮子 \\
\hline
\end{tabular}

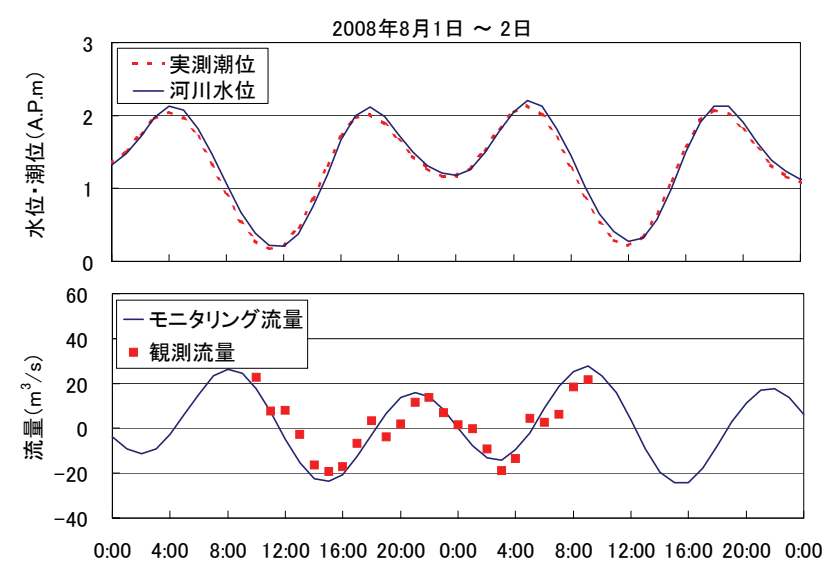

図-2 流量と水位・潮位の時系列変化 (平水時)

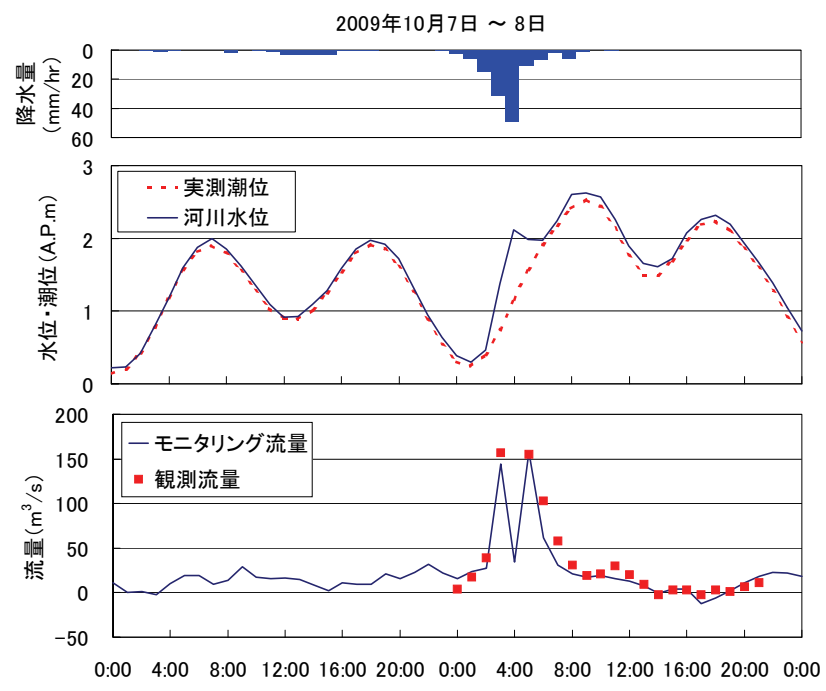

図-3 流量と水位 ·潮位の時系列変化（出水時） 
図-4に，水位変化速度と流量の関係を示寸. 水位変化 速度は1時間あたりの水位変化量を表わしている. 図中 の直線は平水時のデータに対する回帰式を示している. 平水時には水位変化速度と流量の間に線形関係がみられ, 同様の関係は本地点と川幅が同程度である北海道のサロ ベツ川感潮域における流量モニタリングについて報告さ れている7). 図中の回帰式のy切片1.6326は，平水時にお ける潮汐の影響を受けない場合の流量，つまり満潮時お よび干潮時の流量を表していると考えられる. 平水時の 流量時系列の把握は水位のモニタリングのみで可能であ るが，出水時には水位変化速度と流量の間に線形関係は みられない. このため, 出水時の流量時系列を把握する には流速のモニタリングが必要となる. なお, 平水時に おける水位変化速度と流量の回帰式をもとに出水時の流 量を推定した場合, 流量を過少に評価することになる.

\section{3. 水位偏差の要因}

平水時においては水位と潮位に大きな違いがみられな いことから，潮位の予測值である天文潮位と観測水位の 差が河川水位の偏差量を示していると考えられる. 河川 水位から天文潮位を差し引いたものを水位偏差と定義し， 潮汐, 流量, 気圧, 風向・風速が水位偏差に及ぼす影響 を観測データから検討する。図-5に潮汐，流量，気圧， 風向・風速の各項目の観測値と水位偏差をプロットする.

図の(a)は潮位偏差と水位偏差をプロットしている，潮 位偏差は観測された潮位である実測潮位と天文潮位の差 を示している．潮位偏差は気圧，風向・風速の影響を受 けて変化するが，神田川が流入する隅田川の増水の影響 も含んでいる. 潮位偏差の大きいデータに着目すると， 2009年 10 月 8 日と 2008 年 5 月 20 日に $70 \mathrm{~cm}$ 超える潮位偏 差を記録している.このときの隅田川の流域に位置する 気像庁所沢の日降水量を確認すると2009年10月8日には $98.5 \mathrm{~mm} ， 2008$ 年5月20日には $92 \mathrm{~mm}$ を記録している。隅 田川の増水がない場合は潮位偏差と水位偏差は大きくは 違わないものになるが，隅田川の増水がある場合は潮位 偏差と水位偏差に大きな違いが生じるものと考えられる。

図の(b)は潮位変化速度と水位偏差をプロットしている。 潮位変化速度は1時間あたりの天文潮位の変化量を表わ しており，天文潮位から計算される．平水時においては 潮位変化速度が正の值の場合に上げ潮であり, 負の場合 に引き潮になる．潮位変化速度の増加により水位偏差が 小さくなる傾向が見られる.

図の(c)は護岸に取り付けた計器の計測值から推定した 流量（モニタリング流量）と水位偏差をプロットしてい る. 図の流量には直接流出量だけでなく潮汐によって生 じる流量も含まれている. $50 \mathrm{~m}^{3} / \mathrm{s}$ 以上の流量をみると, 流量の増大に伴う水位偏差の増加がみられ, これらの データの水位偏差は流量の影響が大きいものと考えられ

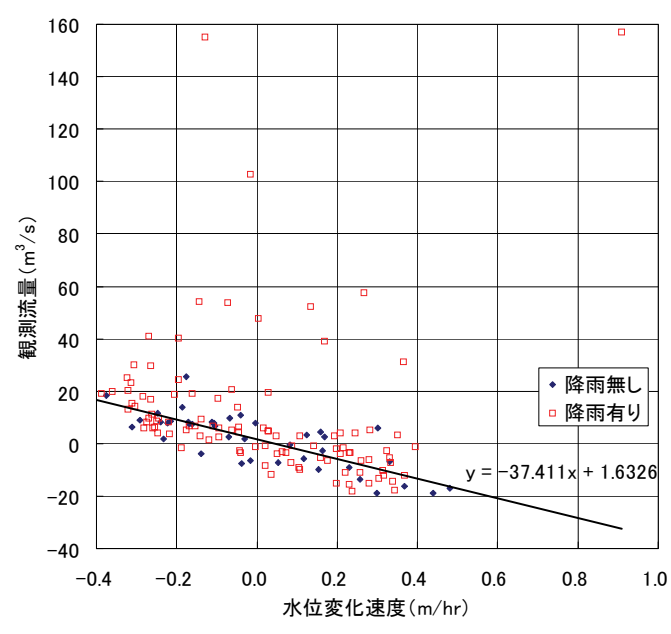

図-4 水位変化速度と流量
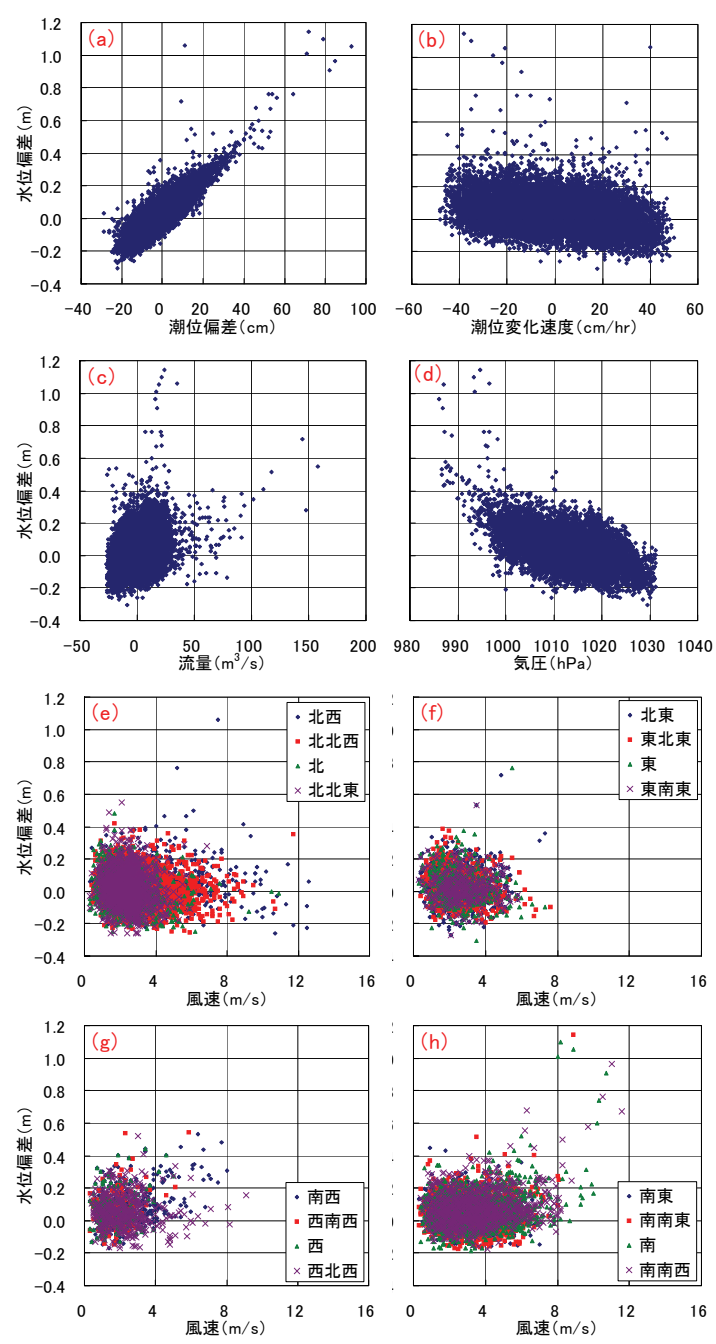

図-5 観測項目と水位偏差

る. 一方， $50 \mathrm{~m}^{3} / \mathrm{s}$ 以下の流量においても $1 \mathrm{~m}$ 超える大き な水位偏差が見られるが，これらのデータは流量以外の 要因によるものだと考えられる.

図の(d)は気圧と水位偏差をプロットしている，気圧は 気象庁東京の海面気圧を用いている. 全体的に気圧の低 下に伴い水位偏差が大きくなる傾向がみられ，0.6m以上 
の水位偏差は気圧1000hPa以下での夕発生している.

図の $(\mathrm{e}) \sim(\mathrm{h})$ は風向別の風速と水位偏差をプロットし ている. 風向と風速は気象庁東京の值を用いている.

(e)〜(h)は風向で区分けしており，(e)は北西から北北東, (f)は北東から東南東，(g)は南西〜西北西，(h)は南東か ら南南西の範囲を表している. (e)と(h)でのみ $10 \mathrm{~m} / \mathrm{s}$ を超 える風速がみられ，大きな風速は南北方向で発生してい る. 風速の増加に伴う水位偏差の変化についてみると (g) と(h)でのみ増加傾向がみられる. 風が水位偏差に及 ぼす影響は，風向によって大きく変化する.

\section{4. 水位流量特性の検討}

\section{（1）ニューラルネットワークモデル（ANN）の適用}

河川計画の検討に用いることを想定し，ANNにより 潮汐，気圧，風向風速を設定した条件下における水位と 流量の関係を検討寸る. 図-5に示した潮汐，流量，気圧， 風向風速のデータを用いて, ANNの学習を行う。本研 究で用いたANNの構造を図-6に示す，入力層，中間層， 出力層の3層からなる階層型ネットワークであり, 各ユ ニットにおいて式(1)および式(2)による計算を行う.

$$
\begin{aligned}
y_{i} & =\frac{1}{1+\exp \left(-x_{i}\right)} \\
x_{i} & =\sum_{i=1}^{n} w_{i j} y_{i}+b_{i}
\end{aligned}
$$

ここに, $y_{i}$ : ユニット $i$ の出力值, $x_{i}$ : 入力值, $w_{i j}$ : 結合 荷重, $b_{i}$ : ユニットiのバイアス值.

水位偏差の計算に用いるANN（水位ANN）は，水位 偏差を出力とし, 入力は流量, 天文潮位, 潮位変化速度, 潮位偏差，気圧，風向，風速としており，流量には降雨 の影響が含まれている．風向は16方位を南北方向と東西 方向の成分に分けて入力する. 水位ANNのユニット数 は入力層 8 , 中間層 8 , 出力層 1 とする. 学習に用いた データは2007年10月から2009年10月の正時データから久 測期間および検証期間を除外したものとし，検証期間は 2008年9月の1ヶ月間とした.

隅田川の増水の影響を考慮する目的で潮位偏差を取り 扱うため，予測計算においては気圧，風向風速によって 生じる潮位偏差を推定する必要がある. 水位偏差同様に ANNを用いて潮位偏差を推定することとし，潮位偏差 の計算に用いるANN (潮位ANN) の入力は気圧，風向， 風速とし, 出力を潮位偏差とする. 潮位ANNのユニッ 卜数は入力層 4 , 中間層 8 , 出力層 1 とする. 学習データ は水位ANN と同様の期間であるが，隅田川の流域に位 置する所沢の前 24 時間降水量が $0.5 \mathrm{~mm}$ 以上を記録してい る期間を除外した。水位ANNの入力の潮位偏差は，学 習には観測值を用い，予測計算には潮位ANNから得ら れた值を用いる．ANNの学習はバックプロパゲーショ ン法帛を用い学習回数は10000とした.

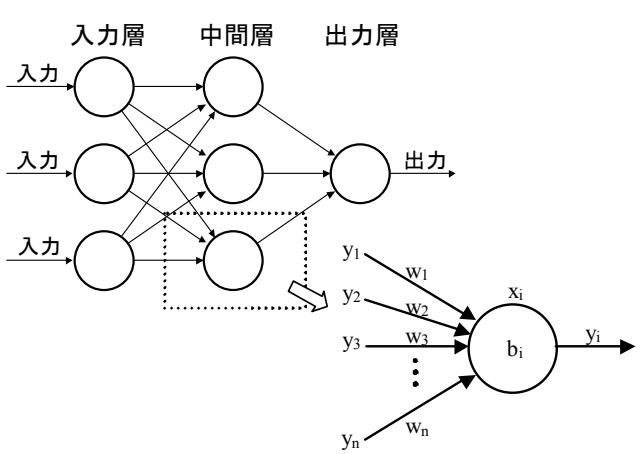

図-6 ニューラルネットワークモデル(ANN) の構造
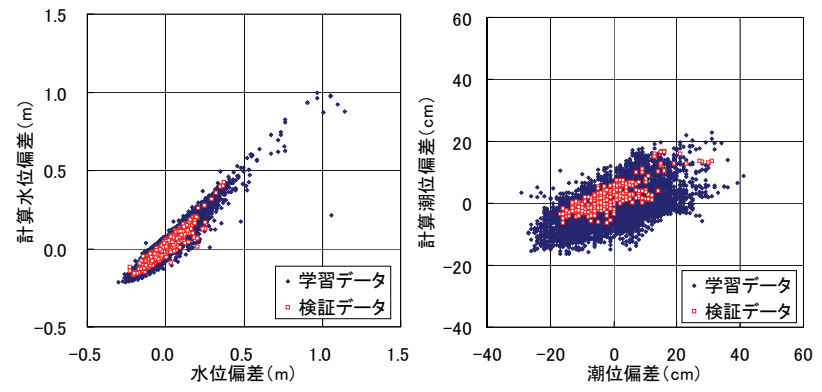

図-7 学習後のANNの再現性
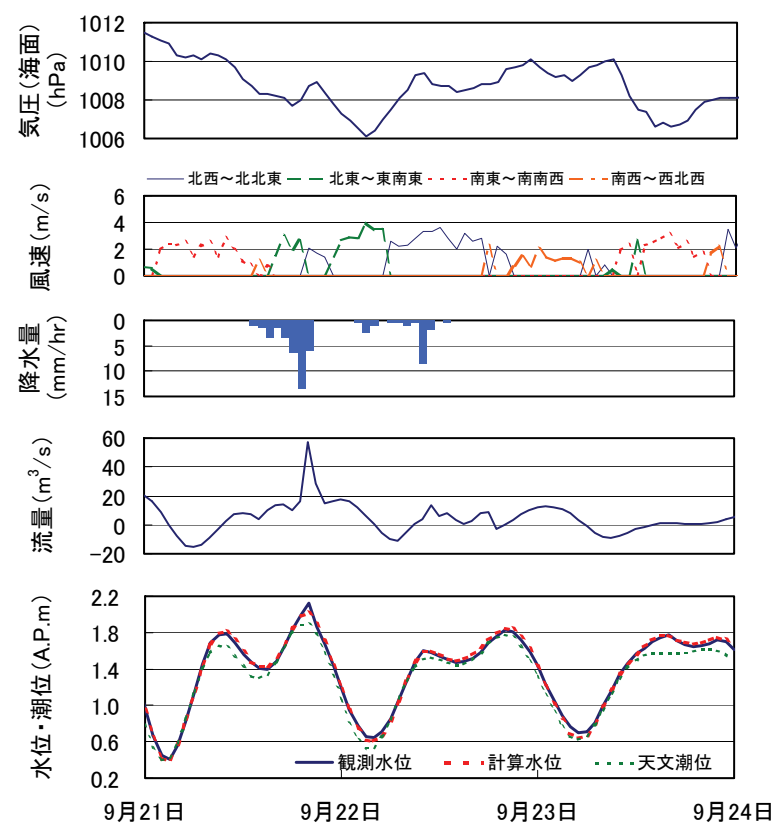

図-8 出水時の再現性

図-7に学習後の水位ANNと潮位ANNの再現性を示寸。 図より水位ANNは高い再現性を有しており, 流量, 天 文潮位，潮位変化速度，潮位偏差，気圧，風向，風速が 得られれば，水位を高精度に推定することが可能である。 一方，潮位ANNについては水位ANNと比べて再現性が 低くなっており, 潮位偏差が得られない状況における水 位の予測は, 誤差を含んだ潮位偏差を入力に用いること によって精度が低下寸ると考えられる.

検証期間における洪水を対象に再現性を確認寸る. 図 -8 に 1 時間 $10 \mathrm{~mm}$ 以上の降水量を観測し $50 \mathrm{~m}^{3} / \mathrm{s}$ 以上の流量 
が発生した2008年9月21日〜24日における河川水位の再 現結果を示す. 約 $60 \mathrm{~m}^{3} / \mathrm{s}$ の流量が発生した 21 日20時を含 め期間全体において計算水位は観測水位を良好に再現し ており, 流量, 天文潮位，潮位変化速度，潮位偏差，気 圧，風向，風速を入力とする $\mathrm{ANN} の$ 利用は感潮河川の 水位推定において有効だと考える.

\section{（2）水位流量特性}

学習を行ったANNを用いて潮汐, 気圧, 風向・風速 を固定した条件下で流量と水位の関係把握を試みる。具 体的には以下の手順で作業を行う．1)各要因が水位偏差 に及ぼす影響が把握できるように天文潮位，潮位変化速 度，気圧，風向，風速，流量を設定する．2)気圧，風向， 風速を潮位ANNに入力し，隅田川の増水がない状況の 潮位偏差を出力する. 3)出力した潮位偏差と天文潮位, 潮位変化速度, 気圧, 風向, 風速, 流量を水位ANNに 入力し水位偏差を出力寸る. 4)出力された水位偏差と入 力に用いた天文潮位の和を計算水位とする．1)から4)の 作業で得られた水位と流量の関係を用いて水位流量曲線 を作成する.ここでは, 治水上の問題となる大潮の状況 において潮汐，気圧，風が水位に及ぼす影響を把握する ため，表-2の計算条件を設定する.

潮汐が水位に及ぼす影響を確認することを目的として, 異なる潮汐条件に対応寸る水位流量曲線を作成する. 計 算条件は表-2の計算条件 $\mathrm{A} \sim \mathrm{D}$ に示寸とおりである. 図9に異なる潮汐条件による水位流量曲線を示寸. なお, 図中の記号は計算条件を表わしている，表-2の計算条件 $\mathrm{A} \sim \mathrm{D}$ に示した潮位变化速度は，順流方向の最大流量発 生時, 満潮時, 逆流方向の最大流量発生時の3ケースに 対応する值を設定しており，図-9ではそれぞれ引き潮， 満潮，上げ潮として表わしている. 気圧の設定值は出水 時の気圧の観測值を参照して決定した．上げ潮において は逆流方向の流量が生じ, 引き潮における最低流量は $0 \mathrm{~m}^{3} / \mathrm{s}$ より大きくなる，流量が同じ場合，上げ潮，満潮， 引き潮の順に流量に占める直接流出量の割合が大きく, 4つの天文潮位に共通して, 引き潮, 満潮, 上げ潮の順 に水位が高くなっている. この水位の違いは流量の増加 に伴って小さくなり, 引き潮と上げ潮による水位の差は 流量 $20 \mathrm{~m}^{3} / \mathrm{s}$ 時に天文潮位によって7〜10 $\mathrm{cm}$ の違いがある が，流量 $150 \mathrm{~m}^{3} / \mathrm{s}$ 時の水位差は天文潮位による違いがみ られず約 $2 \mathrm{~cm}$ になる．異なる天文潮位に対応寸る水位を 比較するため, 水位と天文潮位の差である水位偏差と流 量の関係を考える. 水位偏差と流量の関係をみると，天 文潮位が異なっていても満潮と引き潮については大きな 違いはみられない。満潮時の水位偏差は流量 $20 \mathrm{~m}^{3} / \mathrm{s}$ 時に 約 $8 \mathrm{~cm}$, 流量 $150 \mathrm{~m}^{3} / \mathrm{s}$ 時に約 $23 \mathrm{~cm}$ になり, 引き潮時の水 位偏差は流量 $20 \mathrm{~m}^{3} / \mathrm{s}$ 時に約 $12 \mathrm{~cm}$, 流量 $150 \mathrm{~m}^{3} / \mathrm{s}$ 時に約 $25 \mathrm{~cm}$ になる。

気圧が水位に及ぼす影響を確認することを目的として， 表-2の計算条件 $\mathrm{E} \sim \mathrm{H}$ による水位流量曲線を作成する.
潮位変化速度は，満潮時を想定した值を設定した。なお， 満潮時の河川流量は概ね直接流出量を表していると考え られる. 図-10に異なる気圧による水位流量曲線を示す. 天文潮位が異なっていても水位偏差と流量の関係には大 きな違いがみられない，気圧の低下に伴い水位は上昇し， 天文潮位に拘わらず気圧が $5 \mathrm{hPa}$ 低くなる毎に水位が約 $7 \mathrm{~cm}$ 上昇している.この水位上昇量は流量の大小に拘わ らずほぼ一定である.

表-2 計算条件

\begin{tabular}{|c|c|c|c|c|c|}
\hline $\begin{array}{c}\text { 計算 } \\
\text { 条件 }\end{array}$ & $\begin{array}{c}\text { 天文潮位 } \\
(\mathrm{A} . \mathrm{P} . \mathrm{m})\end{array}$ & $\begin{array}{c}\text { 潮位変化速度 } \\
(\mathrm{cm} / \mathrm{hr})\end{array}$ & $\begin{array}{c}\text { 気圧 } \\
(\mathrm{hPa})\end{array}$ & 風向 & $\begin{array}{c}\text { 風速 } \\
(\mathrm{m} / \mathrm{s})\end{array}$ \\
\hline $\mathrm{A}$ & 1.7 & $-25,10,40$ & 1010 & 北 & 1 \\
\hline $\mathrm{B}$ & 1.8 & $-20,10,35$ & 1010 & 北 & 1 \\
\hline C & 1.9 & $-15,15,30$ & 1010 & 北 & 1 \\
\hline $\mathrm{D}$ & 2.0 & $-10,15,25$ & 1010 & 北 & 1 \\
\hline $\mathrm{E}$ & 1.7 & 10 & $995,1000,1005,1010$ & 北 & 1 \\
\hline $\mathrm{F}$ & 1.8 & 10 & $995,1000,1005,1010$ & 北 & 1 \\
\hline $\mathrm{G}$ & 1.9 & 15 & $995,1000,1005,1010$ & 北 & 1 \\
\hline $\mathrm{H}$ & 2.0 & 15 & $995,1000,1005,1010$ & 北 & 1 \\
\hline $\mathrm{I}$ & 1.9 & 15 & 1010 & 全方位 & 4 \\
\hline $\mathrm{J}$ & 1.7 & 10 & 1010 & 南南西 & $2,4,6$ \\
\hline $\mathrm{K}$ & 1.8 & 10 & 1010 & 南南西 & $2,4,6$ \\
\hline $\mathrm{L}$ & 1.9 & 15 & 1010 & 南南西 & $2,4,6$ \\
\hline $\mathrm{M}$ & 2.0 & 15 & 1010 & 南南西 & $2,4,6$ \\
\hline
\end{tabular}
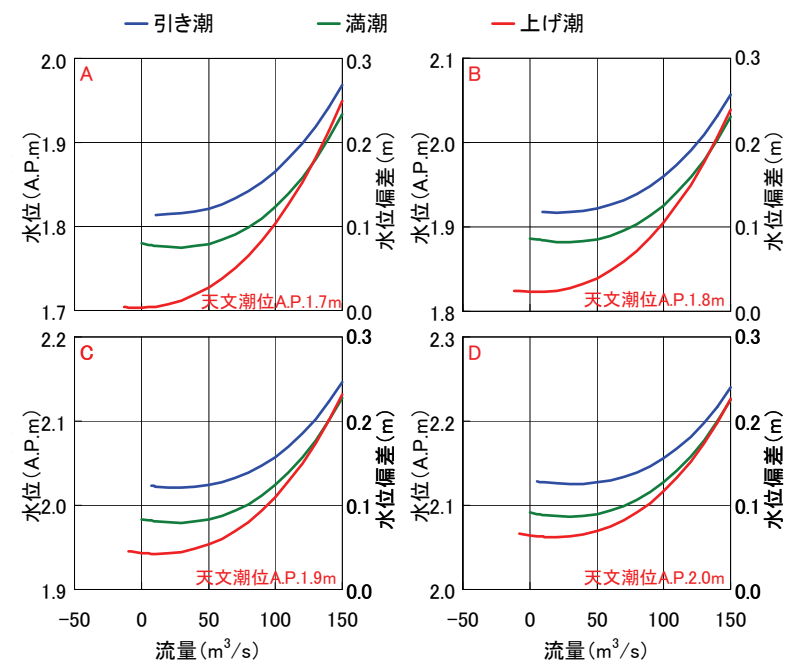

図-9 潮汐による水位流量曲線の変化
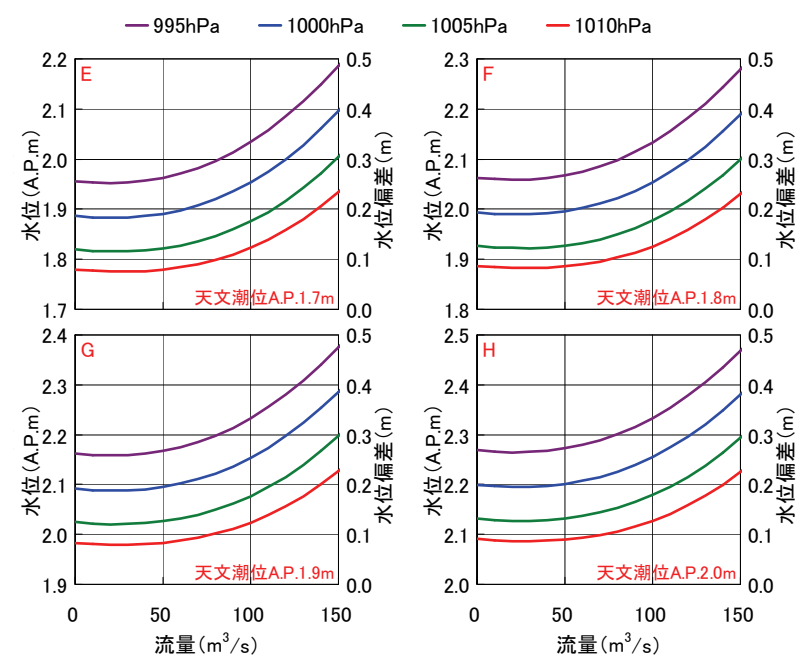

図-10 気圧による水位流量曲線の変化 


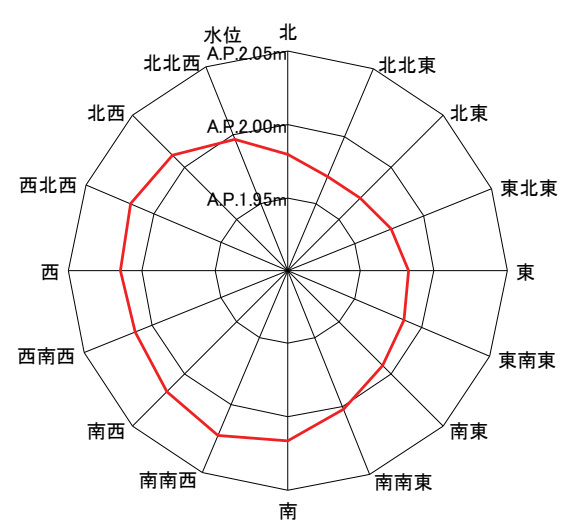

図-11 風向による水位の変化
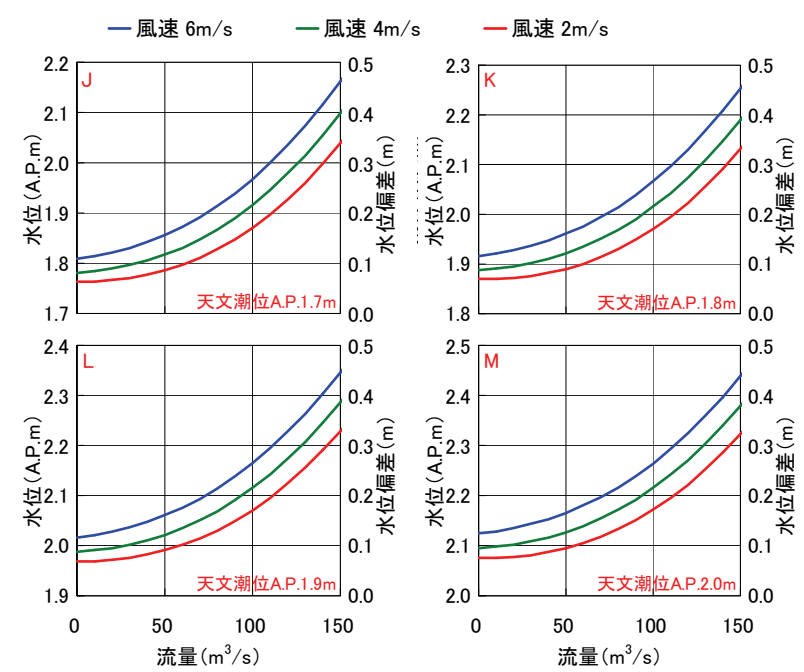

図-12 風速による水位流量曲線の変化

水位に及ぼす風向の影響を把握することを目的として， 表-2の計算条件Iの計算を行う。図-11に各方位に $4 \mathrm{~m} / \mathrm{s} の$ 風速が生じた場合の水位を示寸．風向が南南西の時に水 位が最も高くA.P. $2.02 \mathrm{~m}$ となり，北北東の時に最も低く A.P. $1.97 \mathrm{~m}$ になる. $4 \mathrm{~m} / \mathrm{s}$ の風速に対して風向による水位 の違いは $5 \mathrm{~cm}$ である.

風が水位上昇に及ぼす影響を確認することを目的とし て，水位上昇一の影響が大きい南南西の風向を設定し， 異なる風速に対する水位流量曲線を作成する. 計算条件 は表-2の計算条件J〜Mに示すとおりである. 図-12に南 南西の風向における風速別の水位流量曲線を示寸.4つ の天文潮位に対して水位偏差と流量の関係は概ね同じも のとなっている．風速が $2 \mathrm{~m} / \mathrm{s}$ 大きくなることで流量 $0 \mathrm{~m}^{3} / \mathrm{s}$ 時の水位は約 $3 \mathrm{~cm}$ 上がり, 流量 $150 \mathrm{~m}^{3} / \mathrm{s}$ 時の水位は 約 $6 \mathrm{~cm}$ 上昇する．流量が大きくなると風速が水位に及ぼ す影響は大きくなる.

\section{5. まとめ}

流量が一定值であっても潮汐，気圧，風向風速の条件 によって河川水位に偏差が生じる感潮河川を対象に，水
位と流量の関係把握を試みた。河川モニタリングデータ および気象データをANNに学習させて, 潮汐, 気圧, 風の条件設定を行うことで感潮域において水位流量曲線 を表わした。

作成した水位流量曲線から判断された水位に及ぼす各 要因の影響を以下に示寸. 潮位および流量が同一であっ ても潮位変化速度によって水位は異なり流量が小さい場 合においては，引き潮，満潮，上げ潮の順に水位が高く なる. 流量が大きくなると潮位変化速度による水位の違 いは小さくなる，気圧が $5 \mathrm{hPa}$ 低くなる毎に水位は約 $7 \mathrm{~cm}$ 上昇する. 水位上昇に及ぼす影響が大きい南南西の風向 において，風速が $2 \mathrm{~m} / \mathrm{s}$ 大きくなると流量 $0 \mathrm{~m}^{3} / \mathrm{s}$ 時の水位 は約 $3 \mathrm{~cm}$ 上がり, 流量 $150 \mathrm{~m}^{3} / \mathrm{s}$ 時の水位は約 $6 \mathrm{~cm}$ 上昇する. ANNは学習データに基づいて予測を行うため, 学習 データに含まれていないパターンや学習データより大き な規模の現象に対して予測精度が低下寸る点に注意が必 要であり, 本研究においても計算条件の設定值は, 極力, 学習データに含まれる範囲内となるように心掛けた. な お，計画降雨の確率年が数年程度である都市中小河川で は，数年間の河川モニタリングデータを用いてANNの 学習を行うことにより, 計画高水規模の流量に対しても 適切な予測が可能になると考えられる.

\section{参考文献}

1) 東京都 : 渋谷川・古川河川整備計画, p25, 2008.

2) 満倉真, 貞本均, 中津川誠 : Nearest-Neighbor法による感潮 河川の水位予測, 水文・水資源学会誌, Vol.15, No.4, pp.371-380, 2002.

3) 渡辺直樹, 山根総一郎, 相馬聖二 : 遺伝的プログラミングを 活用した感潮河川におけるリアルタイム水位予測〜横浜市帷 子川を対象とした事例研究〜, 水文・水資源学会2009年度研 究発表会要旨集, 2009.

4) 横尾啓介, 吉田静男, 西田修三，荒川範彦 : 感潮域における 河川水位決定要因の定量的評価, 水工学論文集, 第47巻, pp.961-966, 2003.

5) 安部清明, 㐘池英明, 古川浩平, 塩月善晴 : ニューラルネッ トワークによる流出解析手法（日流量）に関する研究，土木 学会論文集, No.656/II-52, pp.1-13， 2000.

6) 稲吉明男, 長江幸平, 田宮睦雄, 宮田達磨, 眞間修一, 竹村 仁志 : ニューラルネットワークモデルによる二級河川での洪 水予測の基礎的検討，河川技術論文集，第9巻, pp.179-184, 2003.

7) 横尾啓介, 中津川誠，羽山早織，大熊正信 : 超音波式流速計 の連続観測に基づく流量推定手法-河川感潮域を対象として-, 河川技術論文集，第10巻，pp.369-374，2004.

8) 馬場則夫・児島史男・小澤誠一 : ニューラルネットの基礎と 応用, 共立出版, pp.11-20, 1994.

(2010.9. 30受付) 